\title{
Framework Assessment and Index of Knowledge Management of Small Farmers in the Agricultural Area
}

\author{
Veronice, Helmi, Henmaidi, Ernita Arif
}

\begin{abstract}
Knowledge Management (KM) in agriculture is an establishing system for creating, documenting, classifying, and disseminating knowledge, required for synergy of the development of technological innovation dissemination. KM framework requires assessment as a basis for the KM system in agricultural areas as efforts to determine the effectiveness of the system need to have a KM index which serves to represent conditions in the field. This study aims to determine the framework and KM index of small farmers in agricultural areas. Also, evaluating it as a basis for KM systems requires framework assessment in agricultural areas; therefore, the effectivity determination requires a KM index which represents the conditions in the field. The design process uses a Delphi method through the stages, as well as in-depth interviews with 15 experts, observations, and Focus Group Discussion. The result reveals the form of KM index measurement variables within agricultural areas. First, acquisition with indicators of all group member participation in all related activities. This process occurred within and outside the organisation, using a systematic approach. Second, storage with signs of knowledge access owned by all members, which are easily traceable and digitally stored, as well as the existence of information security mechanism. Third, distribution with indicators source, material clarity, and the delivery methods used. And fourth, application with indicators of precise regulation, utilising information technology. The average index results based on the reference of American Productivity and Quality Center (APQC)'s level of Knowledge Management Maturity KM obtained level 3 which is standardisation with the dominant indicator being the acquisition indicator. This study concludes the $\mathrm{KM}$ framework in the agricultural area has four variables, and the $\mathrm{km}$ level index is at level 3.
\end{abstract}

Index Terms: Agricultural area, farmers group,framework assessment, innovation, knowledge management, small farmers, sustainability,

\section{INTRODUCTION}

Small farmers are an essential asset in agricultural development and food security. Small farmers can control their resources, can maintain the relationship between humans and nature, and can reduce dependency. Meanwhile, low-income levels often associate small farmers into the category [1] as one of them is caused by not well-implemented institutions that created this association. Thus, the development of smallholder institutions is one of the problems in agricultural development [2]; [3]; [4]; [5]. Small farmer institutions in agricultural areas need to be developed to overcome every problem such as weak bargaining power, access to capital, access to information and knowledge that is still limited in agricultural management, consequently, production is not optimal [5]. To overcome the limitations of farmers' information and knowledge, they can establish institutional groups to develop their potential and insight in accessing various information [6]. An alternative solution for developing smallholder institutions in agricultural areas is to build productive communities/business units using shared natural and human resources. These alternatives require access to knowledge and innovation management and the ability to continue to survive and compete in the current competition and build potential benefits in increasing

- Department of Agriculture Science, Faculty of Agriculture, Andalas University, Padang 25163, Indonesia. veronice0708@gmail.com

- Department of Socio-economic of Agriculture, Faculty of Agriculture, Andalas University, Padang 25163, Indonesia

- Department Industrial Engineering, Faculty of Engineering, Andalas University, Padang 25163, Indonesia

- Department of Communication Science, Faculty of Social and Political Sciences, Andalas University, Padang 25163, Indonesia information and transferring knowledge [7]. In this connection, the development of an agricultural area known as Knowledge Management needs an integrated approach between expertise and innovation. Knowledge management $(\mathrm{KM})$ is an established system to create, document, classify, and disseminate knowledge in farmer groups so that learning is easy to use whenever needed by anyone. This system is following the level of authority and competence including small farmers, extension agents, traders, Small industries and other stakeholders are involved in the synergy of the development of dissemination of technological innovation in agriculture [8]; [9].

It is necessary to determine $\mathrm{KM}$ in identifying, measuring, and analysing the conditions and processes of KM that occur in agricultural areas to assess the effectiveness of the built system. Based on previous research, KM assessment still uses a technological perspective and is dominated by business organizations and has not touched on aspects of the KM process in small-scale farming communities. This article presents a structural framework for assessing the implementation of knowledge management and analysing the $\mathrm{km}$ index from measurements in the agricultural area.

\section{MATERIALS AND METHODS}

The research data consisted of primary data and secondary data. Primary data are from in-depth interviews with experts, surveys, observations, and Focus Group Discussions (FGD) whereas secondary data are from literature studies in the form of synthesis of journals related to $\mathrm{KM}$ both national and international journals. The population in this study were farmer groups in Lembah Gumanti sub-district, Solok 
Regency, West Sumatra, which involved approximately 14 farmer groups spread across four Nagari (Alahan Panjang, Air Dingin, Salimpat, and Sungai Nanam). Data were analysed qualitatively in case studies. This method allows researchers to understand, examine, and interpret the meanings derived from the phenomena in agricultural areas. This research was carried out through several stages designed to produce an assessment of knowledge management (KM) framework in an agricultural area. These stages are: 1) Collection of knowledge information through observation and Focus Group Discussion (FGD); 2) Develop and build a KM framework with the Delphi method approach. This method is used to obtain input and assessment from experts and practitioners in solving research problems [10]; [11]., states that forecasting, priority issues, identification, and concept development/framework has used this method. In this study involving experts who are experts in the field of agricultural areas; 3) Conduct a KM framework that is prepared using the $\mathrm{KM}$ index based on literature. The intention of the above stages are for: 1) Obtaining a KM framework model in agricultural areas; 2) Obtaining an assessment of the KM framework in agricultural areas.

\section{Results and discussion}

A framework is a concept that illustrates the relevance of potential aspects that affect a system, process, or instrument, and learns how to apply the idea in practice. So this framework can be used as a research tool and used as a guideline about which aspects must be taken into account and considered. The KM assessment framework in small scale agricultural areas is different from that in the business environment. Figure 1 shows The KM framework for the business world. The KM framework in business formulated by CEN contains $5 \mathrm{KM}$ core activities, namely identifying, creating, storing, sharing, and using KM. This framework does not cover the main aspects of KM that are distributed globally but provides such as adding enablers and additional components, or other extension options. Whereas in the area of agriculture classified as a public organisation, based on the results of the Delphi method obtained, it consists of 4 variables from KM, namely acquisition, storage, distribution, and application. Knowledge management acquisition variable is an activity to increase knowledge in farmer groups and is also a process to obtain and collect existing knowledge collections. The scope of the acquisition [13], is to get knowledge from within the farmer groups through the learning process and acquisition of external knowledge through business consultants,

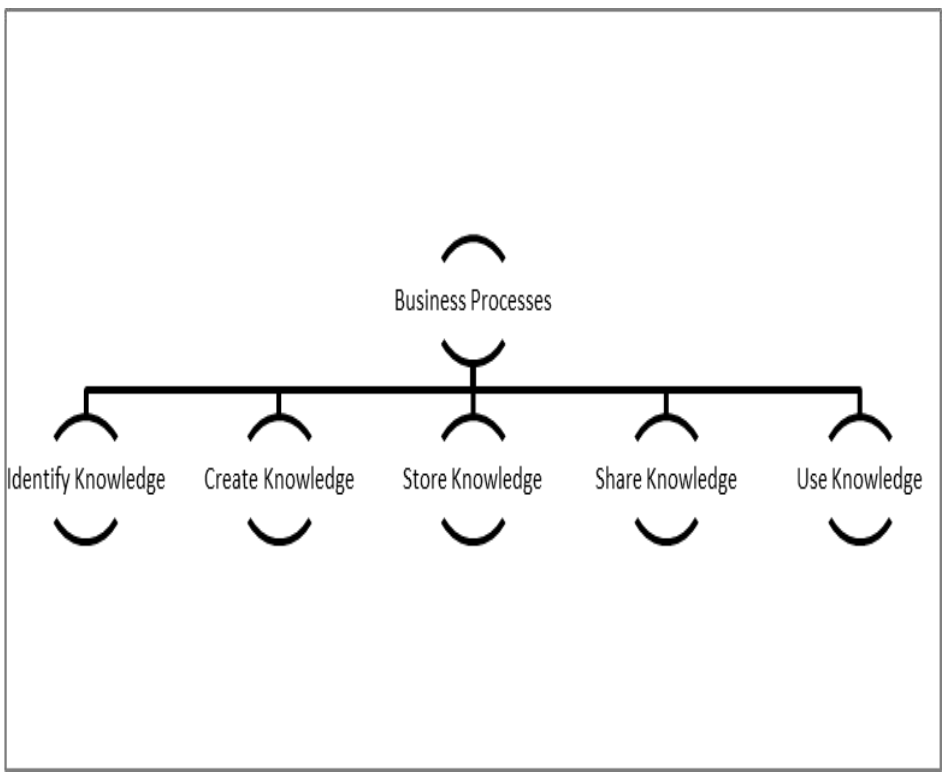

Figure 1. Models of Knowledge Management Framework Assessment in the business world [12]

Associations, universities. In line with what was stated by [14], that $\mathrm{KM}$ acquisition is a farmer group that seeks new knowledge and information inside and outside the farmer group through imitation, benchmarking, replication / outsourcing; there is a collaborative process in obtaining further information. [15] reported that one of the means of knowledge is the acquisition of knowledge is about collecting, combining, connecting information with human experience and expertise. There are four indicators used in this acquisition variable. The first is active member participation: member involvement in achieving goals and taking responsibility in them. The second indicator is the identification of knowledge from within the farmer group: Activities of extracting and gathering information from within the farmer group. The third indicator is the identification of expertise from outside the farmer group: Extracting and gathering information from outside the farmer group. And the fourth indicator is a systematic approach to knowledge creation: Organizational and logical approach to knowledge activities that form a whole, comprehensive, integrated system. KM storage variable is an activity that institutionalises knowledge in the form of farmer group memory and can then be transferred and used in the future. The phase is how to store various information, data, and knowledge well. At this stage, an easily understood form such as documents, manuals, and so on, create new experiences which after that, the knowledge management system stores it. The purpose of this process is that new knowledge is accessible in terms of searching to be used or collaborated and developed [16]. [13], adding that the existence of IT (Information and Technology) must support knowledge storage in individual and farmer groups. Indicators used for storage aspects in this study are Access to member knowledge: Members' ability to use existing knowledge; Kept in the form of documentation or controlled printing; Easy to 
browse and store digitally: A collection of information that can be accessed electronically and printed; The mechanism of securing / storing knowledge: The way or means of rediscovering expertise and information. $\mathrm{KM}$ distribution variable is an activity of knowledge transfer from one party to another. Transfer media that used are through face-to-face discussions/lectures and print media (books, documents, documents) or digital media (email, intranet, and CD ROM). IT application knowledge can be consciously transferred such as written methods such as notes, reports, blackboards; Illegal transfers such as spinning in permanent work, stories and myths, temporary work and informal networks [14]. While [16], argues that capturing and integrating current knowledge is explicit, including internal and external data collection; disseminating explicit knowledge through presentations; process explicit instruction so that it's easier to use. The measurement indicators are Sources of information used People/groups of people who act to make or send news or messages; Clarity of material/messages received: Information/knowledge is delivered to group members or targets in an actual, complete and effective manner; Use of knowledge delivery methods: Systems/methods of implementing learning and information transfer. These indicators measure because one of the objectives of the KM distribution mechanism is to improve the performance of farmer groups and innovation [17]. The KM application variable (knowledge use) refers to the activities of farmer groups that use knowledge to improve the processes, products, services, and performance of farmer groups. [13], the application of $\mathrm{KM}$ is a form of use (exploration/exploitation) dynamic capacity; the search and transformation of knowledge. After transferring/sharing knowledge with others, utilising elaboration (development of different interpretations), identification of underlying problems), and accuracy (development of various understandings by different individuals or groups) are useful in facilitating innovation, learning, or solving the problem. Indicators of this application are There are clear rules/rules: Policies contained in groups to apply information and knowledge; Use of technology and data: Use of information technology used by groups that meet the innovation criteria. Figure 2 represents the model of the $\mathrm{KM}$ framework in the agricultural area.

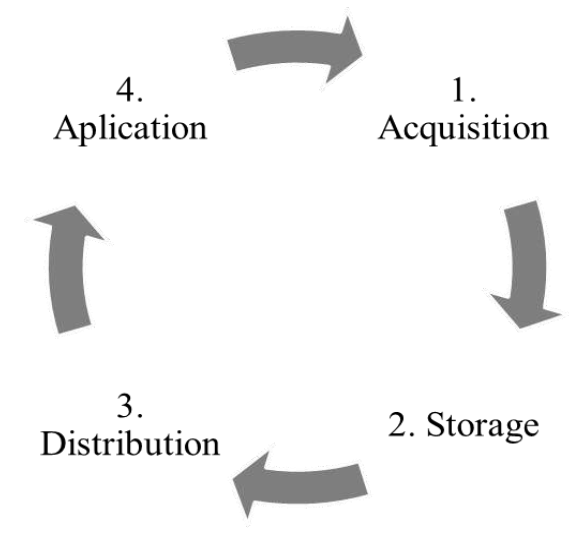

Figure 2. Knowledge Management Framework Assessment in Agricultural Areas.

The KM framework in the established agricultural area is then measured using a Likert scale variable. The Likert scale has five-choice variables in each question to measure individual behaviour, namely strongly agree, agree, not decide, disagree, and strongly disagree [18]. The chosen scale used in this study is STR (Very Irrelevant) $=1$; TR (Not relevant) $=2$; KR (Relevant) $=3$; R (Relevant) $=4$; and SR (Highly Relevant $)=5$. Based on the results of the analysis using the Delphi method, observation, and FGD, the determination of the scale of each indicator in the KM framework measurement. Those are the variables of acquisition, storage, distribution, and application of $\mathrm{KM}$ which divided into several descriptors according to the use of technology and information: The use of information technology used by groups that meet the criteria of existing indicators (12 indicators). A questionnaire from these arranged indicators then distributed to research respondents.

\section{Knowledge Management di at Agricultural Area}

The distribution of questionnaires to 14 farmer groups in the Kecamatan Lembah Gumanti produces a maturity index of each KM variable that is categorizable at each level. The level of this research refers to the level of KM maturity designed by the American Productivity and Quality Center (APQC) which measures KM in five levels: initiate, develop, standardise, optimise, and innovate. APQC's level of Knowledge Management Maturity is designed to help public organisations assess the maturity of achieving goals and infrastructure used, evaluate the process of knowledge flow and supporting approaches, set goals for improving business processes through knowledge flow, the right direction, compare similar efforts between internal units or with external. Besides, APQC's level of Knowledge Management Maturity can define what farmer groups expect to see at each of the five levels of maturity, both in terms of ongoing activities and the capabilities and results obtained [19]. Only one farmer group, Sumber Rezeki, is at level 2. Judging from the total KM index in the Lembah Gumanti sub-district, the KM index is at level 3 with a score of 33.7. Referring to APQC's level of Knowledge Management Maturity illustrated in Table 2, KM in the 
agricultural area is at the standardise level meaning that the process of knowledge flow in the region has been regulated and focused on meeting farmer group requirements, achieving results, and developing supporting infrastructure. This farmer group has a standard knowledge flow process, a KM approach that can replicate, and supporting tools. Also, the obtained measurable results from the $\mathrm{KM}$ assessment indicate that the group already had roles and responsibilities in carrying out the activities of the Whereas the Sumber Rezeki farmer group that has a KM index at level 2 is Developing. This result means that an initial knowledge approach already exists. The focus is on helping local knowledge flow and adding value. Farmer groups have identified opportunities for improvement, and cross-functional groups have responsibilities for setting strategic directions.

Tabel 1: Level Indeks Knowledge Management of Farmers Group at Lembah Gumanti

\begin{tabular}{lllllll}
\hline Farmers Group & Acquisition & Storage & Distribution & Aplication & $\begin{array}{c}\text { KM } \\
\text { Farmers Group }\end{array}$ & Level \\
\hline Aua Sarumpun & 12.3 & 7.00 & 10.0 & 5.83 & 35.2 & 3 \\
Bukik Rajo & 12.5 & 4.75 & 8.67 & 6.00 & 32.0 & 3 \\
Harapan Baru & 12.6 & 6.08 & 8.67 & 6.50 & 34.0 & 3 \\
Harapan Gumanti & 13.3 & 8.11 & 9.67 & 5.78 & 37.0 & 3 \\
Joker merah & 15.1 & 6.46 & 8.69 & 4.85 & 35.1 & 3 \\
Kacang Sajunjuang & 13.4 & 4.86 & 8.71 & 6.00 & 33.0 & 3 \\
Matahari Terbit & 13.0 & 7.43 & 9.00 & 4.43 & 33.9 & 3 \\
Minang Saiyo & 11.5 & 9.07 & 8.29 & 6.36 & 35.2 & 3 \\
Nawaitu Ikhlas & 12.0 & 6.27 & 8.00 & 5.64 & 32.0 & 3 \\
Pawuah Sapakek & 15.0 & 7.00 & 7.00 & 5.80 & 35.0 & 3 \\
Pawuah Sepakat & 16.2 & 7.00 & 5.80 & 5.80 & 35.0 & 3 \\
Sumber Rezeki & 12.3 & 6.69 & 7.13 & 4.25 & 30.4 & 2 \\
Tanjung harapan & 13.0 & 7.91 & 7.91 & 3.91 & 32.7 & 3 \\
Usaha Ikhlas & 12.7 & 6.27 & 9.00 & 5.37 & 33.5 & 33.7 \\
Grand Total & 13.0 & 6.81 & 8.37 & 5.45 & & 3 \\
\hline
\end{tabular}

The variable that has the highest value in the measurement of the KM framework index in the agricultural area, namely Acquisition (Score 13.0), is presented in Figure 3. Involvement of farmer group members in gathering knowledge and information as many as 3-4 activities (out of 5 activities carried out) as in planning events, the decision making process, implementation, benefit-taking, and evaluation of events that will and are ongoing in the group. Participation in group planning involves the involvement of members in programs or activities that are provided such as seedling, land preparation, planting, fertilising, maintaining and handling production. Besides that, the involvement of members in the management of the farming business, consultation between farmers, farmer planning. Planning in the form of member involvement in implementing government programs and group activities for advanced and superior farm processing. Planning for benefits is a form of participation by all group members in getting benefits from programs or activities aimed at increasing income and increasing crop production. Planning the process of making decisions and evaluating activities in groups obtained varied answers due to the involvement of members in decision making and evaluation is not optimal, and the role is taken over by the group administrator.

Table 2: APQC's level of Knowledge Management Maturity

\begin{tabular}{|c|c|c|c|}
\hline Level & Score & Process & Stage Level \\
\hline 1 & $11.9-21.5$ & Initiate & Growing awareness \\
\hline 2 & 21.5-31.2 & Develop & $\begin{array}{l}\text { Localized and repeatable } \\
\text { practices }\end{array}$ \\
\hline 3 & $31.2-40.8$ & Standardize & $\begin{array}{l}\text { Common processes and } \\
\text { approaches }\end{array}$ \\
\hline 4 & $40.8-50.5$ & Optimize & Measured and adaptive \\
\hline 5 & $50.5-60.1$ & Innovate & Continously improving practices \\
\hline
\end{tabular}

The knowledge gained by the group comes from local experience, self-taught, formal member-to-person discussions (meeting of farmers group) and informal talks (julo-julo or social gatherings or working partners on the ground during coffee breaks). 


\section{Total Index KM per Variabel}

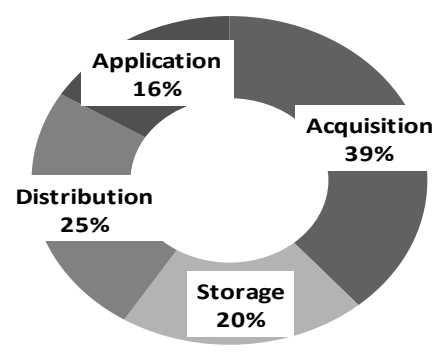

Figure 3. Total Index Knowledge Management per Variable

The process of identifying knowledge that occurs within the farmer group is carried out by all members of the group in 3 or 4 ways. The methods adopted in the process of identifying knowledge from farmers 'groups include the members' knowledge, experience, farmer group documentation, and technology use. The process of identifying knowledge from outside the farmer group has been carried out by all members in 1-2 ways. The methods adopted include benchmarking, expert discussion, reading literature, using media, and collaboration or building alliances. Strengthened by the opinion of [20] that communication and information technology can be used as an appropriate alternative for farmers to use as a medium of communication with the farming community. What most members of this group do is extracting knowledge and information by reading literature and applying media, whereas they never conduct expert discussions, building collaborations or alliances and benchmarking. In terms of the systematic approach in the acquisition or creation of knowledge, groups have an orderly sequence in gaining experience including through experts / experts, the media, research institutions, input institutions, extension workers, fellow farmers, and farmer contacts in obtaining information at the stages of socialization, externalization, combination and internalization. KM distribution (Score 8.37) occupies position 2 in the assessment of variable indices in the agricultural area. Sources of knowledge and information obtained by groups come from 4-6 sources, including researchers, extension workers, farmer contacts, related agencies, production input traders, or NGOs face-to-face and using information media. Likewise, the material or messages given to group members are packaged in a variety of information media, incomplete, not actual, and not appropriate. The method of disseminating knowledge and information is still in the form of lecture and discussion methods while manifesting behaviour change. Furthermore, KM storage (Score 6.81) occupies position 3, with the fact on the ground that all group members already have access to knowledge but have not been stored in the form of controlled documentation or print. Most of the members of the Harapan Gumanti farmer group already have access to knowledge, but it has not stored digitally. Data should be stored digitally to maximise the distribution of information. Because in the opinion of [21], farmers prefer the method of searching through electronic media (digital) rather than manually. And most group members know how to secure knowledge and can use it again. The KM application ranks 4th with an index score of 5.45. Interpreting the results in the field shows as the group has a legal entity that has a formal written rule (AD / ART), it does not have proper administration and does not have productive activities in improving group performance. The use of technology and information refer to group activities that use knowledge to improve the processes, products, services, and production of farmer groups. Also, the experience and data used for groups following the characteristics of members/farmers are challenging to try, difficult to observe, and not yet beneficial to group members. Of the four KM variables above, the expectation of KM implementation at the agricultural area level can be integrated and increase added value. This result is in line with the statements of [22] that knowledge management is an essential element of successful process integration.

\section{Knowledge Management of Farmers Group at Agricultural Area}

Harapan Gumanti farmer group has the highest level of KM application with a score of 36.9 as illustrated in figure 4, while Sumber Rezeki farmer group has the smallest score with a score of 30.4. Harapan Gumanti farmer group, established in 2015, is a beginner farmer group that has a membership of 15 people. The head of the farmer group is always active in mobilising middle-aged members to hold group meetings and activities. This development reinforces ideas by (Site et al 2018) that age can influence information absorption. Young farmers have stronger physical abilities compared to farmers who are relatively old because young farmers are quicker to accept new things, are more willing to take risks, and are more dynamic than farmers. The result of [24] that young farmers have pretty good perception of the work of farming by $66.67 \%$. With an educational background that comes from a university graduate, is not a native citizen and has a high innovation in cultivation and institutions makes other group members motivated to explore information and knowledge. The role of the group leader supported by the part of the extension agents makes the group members have new experience and information obtained for the cultivation activities carried out. Harapan Gumanti farmer groups have superior characteristic compared to several other groups such as having routine group meetings once a month. During the observation, there is the fact that this farmer group could hold meetings more than twice a month, have an agenda every six months or at least once in a year to make visits to farmer groups in other areas in the context of comparative studies as well as the active role of counsellors in guiding farmers. This development follows the statement by [25] that agricultural extension is a way to increase farmers' knowledge to reach the effectiveness of 
farmer groups in managing agriculture correctly and accordingly. Harapan Gumanti farmer group has a complete administration and bookkeeping and has approximately 3 hectares of group area. There is also a gazebo used as a group secretariat. Farmer groups have registered to the Nagari, and government agricultural institutions with the requirements such as the inauguration by Nagari with the presence of extension workers, representation among farmer groups, and officials.

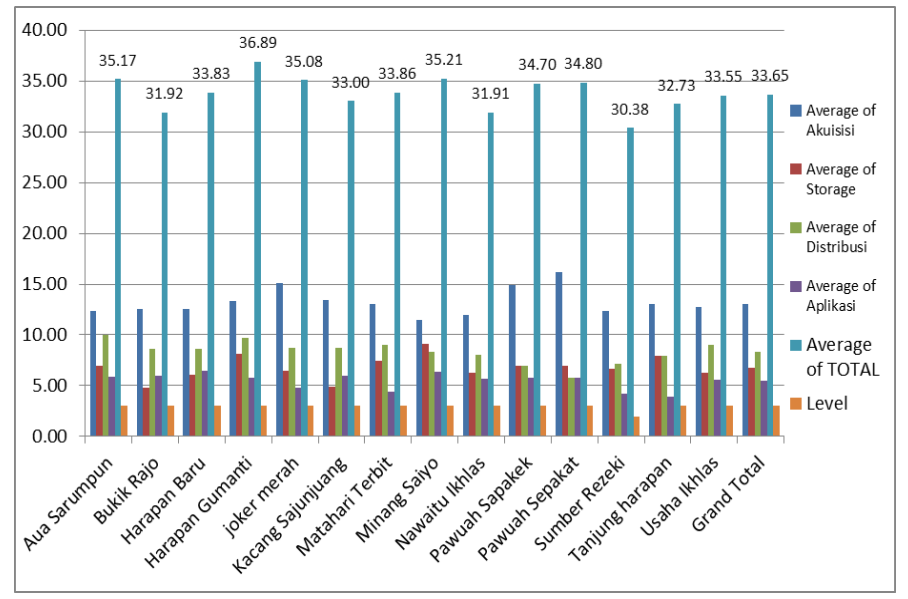

Figure 4. Total Index Knowledge Management per Variable

The results of the study show several causes that farmer groups in Kecamatan Lembah Gumanti were inactive which are uneven distribution of facilities and infrastructure, internal conflicts between fellow management or members motivated by ego and individual interests, ineffective leadership in the group, external factors from advanced farmer groups that weaken the power of novice farmer groups. Some farmer groups only want the programs provided by the government alone without wanting to innovate and form their own group agendas as well as the lack of a strong vision for group formation. Based on [26], the factors needed to increase knowledge sharing are trust, farmer group culture, and appreciation. The emergence of the gap between the average group value obtained by measuring the index of knowledge management is from the low index value of the process of identifying/extracting knowledge from outside the group. This result shows because these farmer groups have activities or programs that are being carried out by the agency resulting in the process of obtaining knowledge from outside the group through relevant stakeholders. Besides, groups that have an index value also have activities from CSR of a state-owned enterprise (SOE) or other company; The index value of the knowledge storage variable is the lowest among all the variables. The knowledge storage index in all farmer groups is low. The fact that groups have not touched digital access is due to the low factor of human resource and the lack of activities or programs from outside parties. In this case the group still expects the role of the agency or extension agents in providing programs or activities to the group. Research result
[27] explain that level of information and communication technology utilization extension agents correlates with the level of extension agents competency The average index value of the knowledge distribution variable also has a low value on the indicator of material clarity or the message received by the method of delivering knowledge. This result is related to the frequency of activities or programs being and will be carried out by the group. The group that has the program or activity will get clear information from the sources and will have various delivery methods. Harapan Baru farmer group shows this result in which their activities or programs are from universities and agency, and the distribution of knowledge they have are very dominant compared to other groups. The Pauah Sapakek farmer group, which is the host of the integrated Pest Control Field Training activities in collaboration with Bank Indonesia, also has a high value of knowledge distribution. The government has made efforts to build and create active and skilled farmer groups such as establishing a field training and institutional management program which this field training is also a form of empowerment for farmers. The statement by [28] supports this community empowerment as a concept of economic development that summarizes social values. Each farmer's group within Kecamatan Lembah Gumanti sends representatives to the field training activity twice a week whether in the field or form of a meeting. The extension agents has a task to guide farmer group members in carrying out these activities in collaboration with private parties working in the field of agriculture. Field training provides opportunities for group members to obtain knowledge acquisition externally. [29] statement that farmers find information from many sources including other farmers, suppliers, extension workers, private parties, agriculture services, researchers Alongside this activity, other solutions for conducting $\mathrm{KM}$ in the agricultural area comprehensively and thoroughly are the need for associations from joint farmer groups and the need for comparative studies to other farmer groups. [30] add that there are six critical factors in KM implementation which are culture, structure, leadership, human resources, information technology, and measurement.

\section{Conclusion}

- Four variables in the assessment of knowledge management frameworks in agriculture are acquisition, storage, distribution, and application.

- Knowledge management in agriculture has a value of 33.7, so it is at level 3 based on APQC's reference level of KM Maturity Knowledge Management. Level 3 is standardised, meaning the process of knowledge flow in the region has been regulated, and the focus is on meeting the requirements of farmer groups, achieving results, and developing supporting infrastructure.

- The farmer group that has the highest KM index is Harapan Gumanti while the lowest is Sumber Rejeki. 


\section{Acknowledgement}

The author thanks the Ministry of Research, Technology and Higher Education of the Republic of Indonesia and Andalas University.

\section{REFERENCES}

Syahyuti 2013 Pemahaman terhadap petani kecil sebagai landasan kebijakan pembangunan pertanian. Forum Penelitian Agroekonomi 31(1) 15-29.

Aminah and Sitti 2015 pembangunan kapasitas petani kecil lahan kering untuk mewujudkan ketahanan pangan. Jurnal Bina Praja I Volume 7 No. 3 Edisi September 2015 : $197-210$

Asta D U, Hubeis and Fatchiya 2015 capacity of cocoa farmers ex coalmining in sawahlunto city, 11 (2).

Saefudin E, Rusmana A and Budiono A 2015 Model manajemen pengetahuan sebagai bentuk diseminasi informasi tanaman obat herbal dan tanaman keluarga. Sosiohumaniora, 17 (2): 100-106.

Anantanyu and Sapja 2011. Kelembagaan petani: peran dan strategi pembangunan kapasitasnya. Jurnal SEPA, Vol. 7 No. 2 Februari 2011: 102-109.

Harahap M and Herman S 2018 Hubungan modal sosial dengan produktivitas petani sayur (studi kasus pada kelompok tani barokah kelurahan tanah enam ratus kecamatan medan marelan). AGRIUM: Jurnal Ilmu Pertanian, 21(2), 157-165.

Badamas M A 2009 Knowledge Management and Information Technology: Enablers of E-Commerce Development." Communications of the IIMA 9.4 (2009): 53-65.

Wang M H and Yang T Y 2016 Investigating the success of knowledge management: An empirical study of smalland medium-sized enterprises. Asia Pacific Management Review, 21 (2): 79-91.

Menaouer B, Khalissa S, Abdelbaki B and Abdelhamid 2015 Towards a new approach of support innovation guided by knowledge management: application on fertial. procedia - Social and Behavioral Sciences210: 260-269.

Rum I A and dan Ratni H 2018 Modul Metode Delphi. Universitas Padjajaran.

Okoli C and Pawlowski S D 2004 The Deplhi Method as a Research Tool: An Example, Design Considerations and Applications, Information and Management Journal (42), page 15-29.

CEN-CWA 14924-1 (2004). Knowledge Management Framework. In European Guide to Good Practice in Knowledge Management (Part 1). Brussels: CEN, CWA 14924-1:2004 (E). Retrieved June 19, 2004, fromftp://cenftp1.cenorm.be/PUBLIC/CWAs/eeurope/ KM/CWA14924-01-2004-Mar.pdf.

Gonzales R V D and Martins M F 2017 Knowledge management process: a theoritical-conceptual research. Gest. Prod, 24(2).
Xue C T S 2017 Literature review on knowledge manajement in organizations. Research in Business and Management, 4 (1): 29-41

Aldin N and Essam 2010 Knowledge management and modern technology. The first copy. Oman: Dar Osama for Publication \& Distribution

Wijaya A E 2014 Model penerapan knowledge manajement system untuk penyususnan tugas akhir berbasis teknologi mobile menggunakan j2me. seminar nasional informastika 2014, page 190-195.

Shen F Y 2018 Knowledge management mechanismsempirical study. Unpublished master thesis, National Tsing Hua University, Hsinchu, Taiwan

Likert R 1932 a Technique for measurement of attitudes. Archives of psychology , 140: 5-55.

APQC. 2017. Knowledge Management Glossary. Retrieved fromhttps://www.apqc.org/knowledgebase/download/ 320028/K05406_KM_\%20kmglossary.pdf (accessed October 1, 2017).

Destrian O U, Wahyudin and Mulyana S 2018 Perilaku pencarian informasi pertanian melalui media online pada kelompok petani jahe. Jurnal Kajian Komunikasi, 6(1), 121-132.

Maryam S M, Hubeis and Maksum 2009 Efektivitas penyebaran informasi di bidang pertanian melalui perpustakaan digital (kasus pusat perpustakaan dan penyebaran teknologi pertanian). Jurnal Komunikasi Pembangunan, 7(1), 65-81.

Fugate B S, Stank T P and Mentzer J T 2009 Linking improved knowledge management to operational and organizational performance. Journal of Operations Management 27;. 247-264.

Site W, Hasan I and Rasyid R 2018 Peran kelompok tani pada pengelolaan usahatani kabupaten luwu utara (studi kasus kelompok tani di desa pararra, Kecamatan Sabbang). Wiratani, 1(1).

Fitriyana E 2017 Persepsi pemuda tani terhadap pekerjaan sebagai petani di kecamatan purworejo kabupaten purworejo (Doctoral dissertation, Universitas Sebelas Maret).

Ngabalin, L. S., Sangadji, S. S., \& Suhardi, S. (2019). Pengaruh Penyuluhan Pertanian Terhadap Efektivitas Kelompok Tani Jaya di Desa Danar Kecamatan Kei-Kecil Timur Selatan Kabupaten Maluku Tenggara. Aksara Public, 3(2), 71-84.

Tan C N L 2016 Enhancing knowledge sharing and research collaboration among academics: The role of knowledge management. Journal of Higher Education, 71, 525556.

Veronice 2015 Analysis level of Utilization Information Communication and Technology with the competency Level of Extension workers. International. Journal on Advanced Science Engineering Information Technology. Vol 5 no 3. 226-229 
Sukendar A, Martalena, Hasuri 2019 Penguatan kapasitas kelompok tani dalam upaya meningkatkan produktivitas budidaya ubi ungu sebagai produk olahan local di Desa Sidamukti Baros Kabupatan Serang. Bantenese journal pengabdian masyarakat, 1 (1).

Ranjbar Z et al 2019. Extension Services And Behavioral Strategies Of Farmers To Deal With Risk. International Journal of scientific \&Technology Research Volume 8, Issue 08,August 2019, 269-274

Rivera G and Rivera I 2016 Design, measurement and analysis of a knowledge management model in the context of a Mexican University. Innovar, 26(59), 21-34. 